\title{
A JURISDIÇÃO CONSTITUCIONAL COMO INSTRUMENTO DE DEFESA DOS DIREITOS FUNDAMENTAIS
}

Fabrício Juliano Mendes Medeiros*

\section{A regularidade das normas jurídicas}

Hans Kelsen leciona que a garantia jurisdicional da Constituição - ou jurisdição constitucional - é um elemento do sistema de medidas técnicas que têm por fim garantir o exercício regular das funções estatais ${ }^{1}$. Funções que podem assumir uma feição jurídica, ou seja, elas podem se consistir em atos jurídicos. É o caso, por exemplo, dos atos de criação das normas jurídicas e de execução de normas jurídicas já criadas.

Interessa, neste estudo, examinar a regularidade da legislação. Sucede que essa tarefa esbarra em algumas dificuldades teóricas. Uma delas é a de que, tradicionalmente, legislação e criação do direito se identificam. Daí porque se tem a impressão de que as funções estatais de mera execução (jurisdição e administração) não criam propriamente o direito, mas simplesmente o reproduzem, uma vez que a sua criação já estaria pronta e acabada.

Tal concepção da relação entre legislação e execução, porém, é deveras inexata. É que essas duas funções estatais (criação e aplicação do direito) não se opõem de forma absoluta. Cada uma delas se apresenta, na verdade, ao mesmo tempo como um ato de criação e aplicação do direito. Para Kelsen, o processo de criação do direito não se cinge à legislação. Ele é deflagrado na esfera da ordem internacional (superior a todas as ordens estatais) e continua na Constituição. Mas não é só: segue as etapas sucessivas constituídas pela lei, pelo regulamento e, em seguida, pela sentença e pelo ato administrativo, até alcançar os atos de execução material destes últimos.

\footnotetext{
*Fabrício Juliano Mendes Medeiros é especialista em Direito Constitucional Processual pela Universidade Federal de Sergipe, Mestrando em Direito e Políticas Públicas pelo Centro Universitário de Brasília UniCEUB, professor de Direito Constitucional do Centro Universitário de Brasília - UniCEUB e Assessor de Ministro do Supremo Tribunal Federal (fabriciojm@stf.gov.br).

${ }^{1}$ KELSEN, Hans. A jurisdição constitucional. São Paulo: M. Fontes, 2003. 
Sabe-se que a Constituição veicula as regras essenciais do processo de elaboração das leis. Assim, a legislação é, em relação à Lei Maior, aplicação do Direito. Já no tocante ao decreto e aos outros atos subordinados à lei, ela (a legislação) é criação do Direito. Dessa forma, o decreto aplica o Direito relativamente à lei e o cria no que diz respeito à sentença e ao ato administrativo. Isso tudo a demonstrar que o Direito, no caminho que percorre desde a Constituição até os atos de execução material, não pára de se concretizar.

Infere-se, portanto, que, por estar subordinado apenas à Constituição, o legislador ordinário se submete a limitações relativamente fracas. $\mathrm{O}$ que faz com que o seu poder de criação normativa permaneça amplo, dado que só deve obediência às determinações jurídicoconstitucionais. Entretanto, a cada grau que se desce, a relação liberdade e limitação de criação normativa se altera em favor desta última. Vale dizer, temos a aplicação do Direito em escala cada vez maior e a sua criação em escala cada vez menor.

Exatamente por essa razão, Kelsen concluiu que "cada grau da Ordem Jurídica, portanto, constitui, ao mesmo tempo, uma produção de direito com respeito ao grau inferior e uma reprodução do direito com respeito ao grau superior"², surgindo, então, a idéia de regularidade do Direito. Regularidade do Direito é, portanto, a relação de conformidade de uma determinada norma jurídica de grau inferior com uma de grau superior ${ }^{3}$. A esse respeito, é oportuno trazer à colação os ensinamentos de Álvaro Ricardo de Souza Cruz ${ }^{4}$, segundo o qual:

Esse modelo trouxe consigo a noção de validade jurídica, ou seja, a conformidade das normas inferiores para com as superiores. Assim, Kelsen (1979) considerava uma norma como vigente/válida, simplesmente porque ela se encontrava de acordo com uma norma jurídica superior.

A Constituição era vista como o ápice de qualquer modelo normativo. Assim, a questão da constitucionalidade das leis cingia-se, inicialmente, no modelo unitário de Kelsen (1979), à conformidade do conteúdo dos atos normativos inferiores com o texto constitucional [...]

O estudo da intitulada jurisdição constitucional exige prévio conhecimento de alguns conceitos técnicos, dentre os quais é de se ressaltar, por primeiro, a noção de

\footnotetext{
${ }^{2}$ KELSEN, Hans. A jurisdição constitucional. São Paulo: M. Fontes, 2003. p. 126.

${ }^{3}$ A respeito da regularidade do Direito em relação à Constituição - assunto que mais diretamente nos interessa nesse estudo - é de se lembrar que Carmem Lúcia Antunes Rocha ensina que "inconstitucional é, pois, o ato normativo ou o comportamento desarmonizado com a Constituição. Esta, que tem força obrigatória vertical superior, é descumprida. Inconstitucionalidade tem sempre o sentido de descumprimento da norma maior e de obrigatoriedade máxima [...]”.ROCHA, Carmem Lúcia Antunes. Constituição e constitucionalidade. Belo Horizonte: Lê, 1991. p. 98.

${ }^{4}$ CRUZ, Álvaro Ricardo de Souza. Jurisdição constitucional democrática. Belo Horizonte: Editoral Del Rey, 2004. p. 115.

PRISMAS: Dir., Pol.Pub. e Mundial., Brasília, v.3, n, 2, p 350-366, jul/dez.2006 
Constituição. E a boa compreensão desse conceito técnico pode ser dada pelo modelo hierárquico da Ordem Jurídica ideado por Kelsen.

Deveras, a noção de Constituição passou por várias alterações, mas sempre conservou um núcleo permanente, qual seja ${ }^{5}$ :

[...] a idéia de um princípio supremo determinando a ordem estatal inteira e a essência da comunidade constituída por essa ordem. Ela sempre é fundamento do Estado, a base da ordem jurídica que se quer apreender [...].

É esse núcleo permanente que nos remete à idéia de que a Constituição -exatamente por ser o pilar de uma determinada Ordem Jurídica -- é a norma que disciplina o processo de elaboração das leis e das normais gerais que legitimam a atividade dos organismos estatais, dos tribunais e das autoridades administrativas. Em suma, é a Constituição um repositório das normas que regulam o procedimento da legislação, inclusive no tocante à distribuição de competência entre os órgãos e autoridades estatais partícipes do processo legiferante.

Por esse motivo, é absolutamente necessário proporcionar a maior estabilidade possível às normas constitucionais. Uma estabilidade, acresça-se, capaz de justificar o dificultoso processo de alteração constitucional, se comparado com os processos de alteração das demais espécies normativas. É a partir da idéia de reforma constitucional por um método legislativo exigente de condições difíceis de serem reunidas que surge a dicotomia forma constitucional e forma legislativa ordinária. Mais: como é a Lei Fundamental de um país quem estabelece o processo de elaboração das espécies normativas e os respectivos protagonistas (órgãos e autoridades públicas), qualquer desrespeito às normas constitucionais atinentes ao processo legislativo contamina formalmente o próprio produto do parlamento.

Nesse rumo de idéias, cabe aqui mencionar que a noção de Constituição também assume um sentido mais amplo. Além de contar com regras que estabelecem os procedimentos e os órgãos legislativos, a Lei das Leis também incorpora um catálogo de direitos fundamentais do indivíduo. Conseqüentemente, ela não traça tão-somente o itinerário a ser seguido pelo legislador na elaboração da vontade geral, mas estabelece limites a sua autuação. Assim, uma determinada espécie normativa elaborada em plena conformidade com as regras procedimentais é formalmente constitucional. Entretanto, essa mesma espécie

\footnotetext{
${ }^{5}$ KELSEN, Hans. Ob. cit., p. 130. 
normativa, ainda que formalmente válida, pode ser materialmente inconstitucional, se o legislador olvidar alguma limitação a ele imposta pela Lei Fundamental ${ }^{6}$.

Bem de ver, por outro lado, que a ampliação da noção de Constituição também traz uma outra importante conseqüência. Os dispositivos constitucionais referentes ao processo legislativo e ao conteúdo das leis somente pelas leis podem ser atendidos. Sendo assim, as garantias constitucionais ficariam restritas a um conjunto de meios contra leis inconstitucionais. Todavia, quando a noção de Constituição é ampliada a outros objetos que não o procedimento legislativo e o conteúdo das leis, torna-se possível que a Lei Maior se concretize por intermédio de outras formas jurídicas que não sejam leis. Ou seja: o alargamento da noção de Constituição aumenta o seu espectro de concretização, aumentando, por conseqüência, as garantias constitucionais.

Foi o próprio Kelsen que detectou a existência dos atos normativos primários e secundários, de modo a separar aqueles que retiram o seu fundamento de validade diretamente da Constituição daqueles que o fazem de forma apenas mediata. Sendo assim, se algum ato normativo decorrente diretamente da Constituição (ato normativo primário) for com ela incompatível tem-se a chamada inconstitucionalidade imediata, direta, chapada. Ao contrário, quando um ato normativo retira da Constituição o seu lastro de validade de forma apenas indireta (ato normativo secundário) e com ela está em desarmonia, podemos dizer que esse ato é igualmente inconstitucional; mas, nessa hipótese, a inconstitucionalidade só se opera de maneira reflexa, oblíqua, indireta.

\section{As garantias da constitucionalidade}

Depois de examinado o problema da regularidade das leis e a noção de Constituição, convém estudar as garantias necessárias à sua proteção. Antes, porém, é mister tecer alguns comentários a respeito dos dois pilares da jurisdição constitucional: a rigidez constitucional e a supremacia da Constituição.

Nesse sentido, é de se ver que o conceito de rigidez constitucional deita raízes na construção jurisprudencial da Suprema Corte dos Estados Unidos e está sempre ligado à idéia de um procedimento especialíssimo de reforma constitucional. Em outras palavras:

\footnotetext{
${ }^{6}$ A esse respeito, escreveu Manoel Gonçalves Ferreira Filho: “[...] Assim, a validade da lei depende, por um lado, de um condicionamento formal. Este resulta das normas que regem o processo de sua elaboração (competências, prazos, etc.). Mas igualmente de um condicionamento material. De fato, o conteúdo da lei tem de estar sintonizado com as regras materiais que edite a Constituição. Isto quer dizer que, havendo a Constituição preordenado o conteúdo da lei, esta não pode contradizê-lo sob pena de invalidade". FERREIRA FILHO, Manoel Gonçalves. Direitos humanos fundamentais. 6. ed. São Paulo: Saraiva, 2004. p. 110-111. 
Constituição rígida é aquela "somente alterável mediante processos, solenidades e exigências formais especiais, diferentes e mais difíceis que os de formação das leis ordinárias ou complementares"

De sua parte, é o postulado da rigidez constitucional que justifica o ideário de supremacia da Constituição. Como bem salienta José Afonso da Silva ${ }^{8}$ :

Da rigidez deflui, como primordial conseqüência, o princípio da supremacia da constituição que, no dizer de PINTO FERREIRA, é um princípio basilar de direito constitucional moderno. Significa que a constituição se coloca no vértice do sistema jurídico de um país, a que se confere validade, e que todos os poderes estatais só são legítimos na medida em que ela os reconheça e na proporção por ela distribuídos. É, enfim, a lei suprema do Estado, pois é nela que se encontra a própria estruturação deste e a organização de seus órgãos; é nela que se acham as normas fundamentais do Estado, e só nisso se notará sua superioridade em relação às demais normas jurídicas.

É a supremacia da Constituição, portanto, que fundamenta a validade das normas jurídicas inferiores. Não é só. É desse postulado que resulta toda a idéia de regularidade das leis tratada no tópico anterior. A idéia de relação de conformidade de uma determinada norma jurídica de grau inferior com uma de grau superior, de modo que as normas inferiores serão inválidas se incompatíveis com as de superior hierarquia?

Fixadas essas premissas é de se retornar ao estudo das garantias da Constituição, a significar o conjunto de medidas técnicas elaboradas e desenvolvidas para o fim de assegurar a regularidade dos atos estatais em geral.

As garantias da Constituição podem assumir feições preventivas e repressivas. As garantias preventivas têm a função de impedir a produção de atos irregulares, ou seja, atos incompatíveis com uma norma hierarquicamente superior. Já as repressivas reagem contra o ato irregular uma vez produzido. Além disso, tendem a impedir a renovação de malfadado ato estatal no futuro, a reparar o dano que ele causou, a fazê-lo desaparecer e, eventualmente, a substituí-lo por um regular.

Vários são os exemplos de garantias puramente preventivas, entre as quais podemos citar a responsabilização penal, civil e disciplinar do órgão que produziu um ato

\footnotetext{
7 SILVA, José Afonso da. Da jurisdição constitucional no Brasil e na América Latina. In. Revista da Procuradoria Geral do Estado de São Paulo, São Paulo, no 13/15, p. 111, dez/1978-dez/1979.

${ }^{8}$ Ibidem, p. 111.

9 A esse respeito, precisas foram as palavras do Chief-Justice of the United States of America, John Marshal, quando do julgamento do célebre caso Marbury versus Madison: "Ou havemos de admitir que a Constituição anula qualquer medida legislativa, que a contrarie, ou anuir em que a legislatura possa alterar por medidas ordinárias a Constituição. Não há como contestar o dilema. Entre as duas alternativas não se descobre meio termo. Ou a Constituição é uma lei superior, soberana, irreformável por meios comuns; ou se nivela com os atos de legislação usual, e com estes, é reformável ao sabor da legislatura”. BARBOSA, Ruy. A Constituição e os atos inconstitucionais do Congresso e do Executivo. 2. ed. Rio de Janeiro: Atlântica, 1893. p. 46.

PRISMAS: Dir., Pol.Pub. e Mundial., Brasília, v.3, n, 2, p 350-366, jul/dez.2006 
irregular, a fim de evitar a repetição dessa prática. Sucede que, embora plenamente possível no tocante à aplicação da legislação, a responsabilidade constitucional e civil dos órgãos que produzem atos irregulares não pode atingir o Parlamento como tal ou aos seus membros. Assim, os indivíduos associados à legislação - Chefes de Estado, Ministros etc. - podem ser responsabilizados pela inconstitucionalidade das leis, notadamente se a Constituição dispuser que eles assumem, pela promulgação ou pela sanção, a responsabilidade pela constitucionalidade do processo legislativo ${ }^{10}$.

Já em relação às garantias puramente repressivas, podemos destacar a nulidade do ato irregular. Mas o que é um ato nulo? É algo que pretende ser um ato jurídico (especialmente um ato estatal), mas não o é, objetivamente, por ser irregular, isto é, por não atender aos requisitos prescritos por uma norma jurídica hierarquicamente superior. $\mathrm{O}$ ato nulo, portanto, carece, de antemão, de todo e qualquer caráter jurídico, de modo que não é necessária a edição de um outro ato estatal válido para substituí-lo.

Sem embargo de dúvida, de todas as garantias à Constituição já idealizadas pela doutrina moderna, a anulabilidade do ato inconstitucional é a que representa a principal e mais eficaz garantia da Lei Fundamental de uma determinada Nação ${ }^{11}$.

É convir: absolutamente tentadora é a proposta de confiar a anulação dos atos irregulares ao próprio órgão que os produziu. Ocorre que essa proposta é, a um só tempo, extremamente tentadora e absolutamente inútil. Isto porque é de se admitir que seja o parlamento eficazmente compelido a anular um ato tido por inconstitucional. Portanto, não é com a Casa Legislativa que se pode contar para lhe impor a supremacia da Constituição. Essa tarefa deve ser reservada à jurisdição constitucional ou um tribunal tipicamente constitucional $^{12}$.

Sem demora, alguns estudiosos ensaiam algumas críticas e objeções a essa idéia. De todas elas, é de se emprestar maior relevo àquela que aponta violação ao princípio da Separação dos Poderes.

${ }^{10}$ KELSEN, Hans. A jurisdição constitucional. São Paulo: M. Fontes, 2003. p. 149.

${ }^{11}$ Comentando a Constituição de 1891, Ruy Barbosa afirmou que a nulidade do ato inconstitucional é uma verdade obvia e definitiva da jurisprudência constitucional brasileira. Advertia Ruy, referindo-se às lições de Dicey, que "Onde se estabelece uma Constituição, com delimitação da autoridade para cada uma dos grandes poderes do Estado, claro é que estes não podem ultrapassar essa autoridade, sem incorrer em incompetência, o que em direito equivale a cair em nulidade". BARBOSA, Ruy. Comentários à Constituição Federal Brasileira. São Paulo: Saraiva, 1932-1934. p. 7.

${ }^{12}$ Segundo Javier Perez Royo, a jurisdição constitucional é decisiva para o Estado democrático, uma vez que ela condiciona a interpretação da Constituição pelas Câmaras Legislativas. É dizer: de um sistema de interpretação parlamentar inicial e incondicionada, passa-se a uma outra forma de interpretação parlamentaria também inicial, mas condicionada. Condicionada exclusivamente pela Constituição, mas tal como definida por outro órgão: o Tribunal Constitucional. ROYO, Javier Perez. Tribunal constitucional y division de poderes. Madrid: Tecnos, 1988. p. 21. 
Em verdade, não se pode negar que a anulação do ato inconstitucional pelo Tribunal Constitucional representa a intromissão de um órgão estranho ao legislativo neste poder. No entanto, a idéia de que a atuação do Tribunal Constitucional viola a Separação dos Poderes perde sentido quando se constata que tarefa de anular leis incompatíveis com o Texto Maior não é tipicamente jurisdicional ${ }^{13}$. E não é jurisdicional porque anular um ato do Poder Público inconstitucional é estabelecer uma norma geral de conteúdo negativo, uma vez que a anulação de uma lei tem o mesmo caráter de generalidade que o de sua elaboração.

Sendo assim, é forçoso reconhecer que a anulação, pelo Tribunal Constitucional, de uma lei incompatível com a Lei Máxima o qualifica como legislador negativo (ou contralegislador).

Neste cenário, ao invés de representar violação ao princípio da Separação dos Poderes -- que hoje em dia deve ser encarado mais como divisão do que separação de Poderes --, a jurisdição constitucional é afirmação desse princípio. Isto porque, ao impedir a concentração de poder excessivo nas mãos de um só órgão estatal, a jurisdição constitucional também garante a regularidade do funcionamento de diferentes órgãos.

Ademais, cabe averbar que a mesma idéia que sustenta a tese de violação à Separação de Poderes pelo Tribunal Constitucional também poderia ser transportada para o caso no qual o Chefe do Poder Executivo veta um projeto de lei enviado pelo parlamento. Algumas vozes também poderiam se levantar para dizer que a atuação do Executivo representaria uma ingerência de um poder sobre o outro. Contudo, ninguém se habilita a verbalizar tal entendimento, dado que o Chefe do Poder Executivo recebeu da própria Constituição o poder-dever de vetar o projeto legislativo com ela incompatível. Aliás, como bem ensina Montesquieu, "o poder executivo, como dissemos, deve participar da legislação através do direito de veto, sem o que seria despojado de suas prerrogativas" 14 .

E com a jurisdição constitucional não é diferente. A anulação de uma lei tida por inconstitucional é realizada por intermédio de aplicação direta das normas constitucionais. Assim, diferentemente do legislador positivo -- que só está jungido à Constituição quanto à forma e, excepcionalmente, quanto ao conteúdo --, a atividade do legislador negativo (da Corte Constitucional) é absolutamente subordinada à Lei das Leis. Portanto, tanto o veto jurídico por inconstitucionalidade como a anulação de uma lei inconstitucional pelo Tribunal

\footnotetext{
${ }^{13}$ Não é por outro motivo que alguns estudiosos (forrados de razão, diga-se de passagem) defendem a tese de que, ao exercer o controle de constitucionalidade em tese, o Tribunal Constitucional não desempenha atividade jurisdicional.

${ }^{14}$ MONTESQUIEU. O espírito das leis. Brasília: Editora UnB, 1995. p. 193.

PRISMAS: Dir., Pol.Pub. e Mundial., Brasília, v.3, n, 2, p 350-366, jul/dez.2006 
Constitucional são atividades desempenhadas debaixo dos limites impostos pela própria Lei Máxima ${ }^{15}$.

Bem vistas as coisas, então, cumpre afirmar que a jurisdição constitucional é uma decorrência do próprio Estado de Direito, no qual o legislador se encontra vinculado ao direito. Assim, na medida em que a Constituição traça o iter a ser seguido pelos personagens do processo de produção das leis e, em alguma medida, o seu conteúdo, confere legitimidade à jurisdição constitucional para sindicar o Executivo e o Legislativo, que são os partícipes desse processo.

Nesse fluxo de idéias, merece lembrança as palavras do Otto Kimminich ${ }^{16}$, para quem:

O Estado de Direito vincula o legislador ao direito. Essa idéia, que já dominava o Estado de Direito da monarquia constitucional, há de se fazer presente, de forma ainda mais marcante, no Estado de Direito democrático da República. Essa vinculação expressa a necessidade de controle dos atos políticos, uma vez não subsistir dúvida quanto à natureza política da legislação. Esse controle deve impedir que o Estado de Direito democrático se perverta em uma ditadura parlamentar da maioria.

A outorga de competência a uma instância jurisdicional para a aferição da compatibilidade do direito ordinário com norma superior, levada a efeito pela Lei Fundamental, não constitui obra do acaso, mas é uma conseqüência do princípio do Estado de Direito, que exige um controle jurisdicional, isto é um controle independente.

Infere-se, portanto, que, entre as garantias da constitucionalidade, a anulação do ato inconstitucional por um órgão incumbido nessa tarefa é aquela que mais eficazmente alberga a higidez da Lei Maior. Assim, legitimada pela própria Norma Normarum, o Tribunal Constitucional exerce o controle dos atos do Poder Público, controle, esse, que se justifica ainda mais num Estado Democrático de Direito, no qual as atividades legislativa, executiva e judiciária nascem devidamente condicionadas pela vontade constitucional.

\section{A jurisdição constitucional como instrumento de proteção dos direitos fundamentais}

Na esteira dos ensinamentos de Pinto Ferreira

[...] a jurisdição constitucional é a parte da administração da Justiça que tem como objeto específico a matéria jurídico-constitucional de um Estado. Ela verifica se as normas de hierarquia inferior estão de acordo com a

15 De se lembrar que, no caso do Brasil, o Supremo Tribunal Federal recebeu expressamente da própria Constituição Federal de 1988 a nobre tarefa de guardá-la, conforme preceitua o artigo 102 da Carta-cidadã.

${ }^{16}$ KIMMINICH, Otto. A jurisdição constitucional e o princípio da decisão de poderes. Revista de Informação Legislativa, Brasília, v 27, nº 105, p. 286, jan/mar-1990.

PRISMAS: Dir., Pol.Pub. e Mundial., Brasília, v.3, n, 2, p 350-366, jul/dez.2006 
Constituição como lei fundamental, e, se a contradizem, devem ser declaradas inconstitucionais, sendo, por conseguinte, inaplicáveis. ${ }^{17}$

No entanto, a jurisdição constitucional não se resume ao controle de constitucionalidade. Este é, tão-somente, um dos aspectos da jurisdição constitucional ${ }^{18}$.

No Estado Democrático, a jurisdição constitucional adquire uma importância vital, que varia de acordo com os traços característicos da Constituição individualmente considerada $^{19}$. Ao estabelecer a Constituição a elaboração das leis, e em particular sua constitucionalidade material, a jurisdição constitucional torna-se um meio eficaz de proteção da minoria contra os atropelos da maioria e até mesmo contra os atropelos das maiorias eventuais. $^{20}$

Em verdade, a democracia pode ser definida como um regime de governo e de sociedade em que a vontade geral (ou a ordem social) é construída por quem está a ela submetido, ou seja, o próprio povo. Em pouquíssimas palavras, democracia consiste num regime de governo e de sociedade na qual o povo participa ativamente da tomada das decisões. A seu turno, a pretensão do sistema democrático é a de que a maioria represente também a minoria, ou seja, a vontade da maioria seria também a vontade da minoria. Sucede que, na realidade, não se pode afirmar que a minoria tem a sua vontade exercida pela vontade da maioria.

Na prática, a minoria (ainda que legitimamente derrotada) conserva seus ideais. Exatamente por isso ela deve ter à sua disposição mecanismos eficientes de influir na vontade da maioria, uma vez que, do contrário, cedo ou tarde a minoria renunciará à participação no processo de formação da vontade geral. Desnaturando, assim, a própria maioria, que não existe sem minoria. Daí a importância do papel a ser desempenhado pela jurisdição constitucional, porquanto, como afirmado por Kelsen, a proteção da minoria se dá mediante a

\footnotetext{
${ }^{17}$ FERREIRA, Pinto. O judiciário e a constituição. São Paulo: Saraiva, 1994. p. 198.

18 "O sistema de controle da constitucionalidade e da jurisdição constitucional deve visar também, e especialmente, a proteção das liberdades. Daí as suas linhas principais: a) a impugnação da inconstitucionalidade das leis (Normen-kontrolle); B) o recurso específico contra a violação dos direitos do homem (Beschwerde). O recurso Beschwerde tem natureza constitucional e importância decisiva na tutela jurisdicional dos direitos do homem previstos na Constituição, e pode ser interposto por qualquer pessoa que tenha tido os seus direitos fundamentais violados por leis ou por atos e resoluções federais e estaduais". Ibidem, p. 198.

19 A propósito, convém lembrar as palavras do Professor Paulo Bonavides: “[...] A época constitucional que vivemos é a dos direitos fundamentais que sucede à época da separação dos poderes. Em razão disso, cresce a extraordinária relevância da jurisdição constitucional, ou seja, do controle de constitucionalidade, campo de batalha da Lei Fundamental onde se afiança juridicamente a forma legitimadora das instituições. Em verdade, a justiça constitucional se tornou uma premissa da democracia: a democracia jurídica, a democracia com legitimidade." BONAVIDES, Paulo. Jurisdição constitucional e legitimidade: algumas observações sobre o Brasil. Anuário Iberoamericano de Justiça Constitucional, São Paulo, v. 7, 2003, p. 77-78.

${ }^{20}$ Cf. MS 24.849, Relator Min. Celso de Mello, DJ, 29/09/2006, p. 34.

PRISMAS: Dir., Pol.Pub. e Mundial., Brasília, v.3, n, 2, p 350-366, jul/dez.2006 
garantia das liberdades públicas, que será desempenhada por um Tribunal Constitucional ${ }^{21}$. A esse respeito, aliás, cabe trazer à colação o ponto de vista de Gustavo Binenbojm ${ }^{22}$ :

[...] o controle de constitucionalidade deve preocupar-se fundamentalmente com a preservação das liberdades que preservem abertos os canais da participação política, tais como as liberdades de expressão, de consciência, de associação e o voto universal, secreto, igualitário e periódico. Qualquer bloqueio nos canais da mudança política, de molde a perpetuar determinados grupos no poder ou dele alijar sistematicamente outros, compromete o bom funcionamento do regime democrático. Além disso, cabe à Corte Constitucional facilitar a representação das minorias, sustando leis que exibam caráter discriminatório e, como tal, representem risco para a higidez do sistema representativo. [...]

Noutra vertente, é de se concluir que até mesmo o princípio da rigidez constitucional revela a especial preocupação da Lei Maior com as minorias. Sim, porque as alterações mais profundas e substanciais no Ordenamento Jurídico só poderão ser perpetradas com a participação dela, minoria ${ }^{23}$.

Pode-se, então, tranqüilamente concluir que a jurisdição constitucional também se destina à proteção das liberdades públicas frente ao poder estatal. Até porque não é de se esquecer que, modernamente, grande parte dos direitos fundamentais foram positivados pelas próprias constituições, sendo, por esse caminho, incorporados aos respectivos ordenamentos jurídicos ${ }^{24}$.

Cabe abrir um parêntese para dizer que, no caso da Constituição brasileira de 1988, houve uma extrema boa vontade do legislador constituinte. Fruto, lógico, da quadra histórica que antecedeu a instalação da Assembléia Nacional Constituinte de 1986/1987. E quando se diz boa vontade do legislador constituinte não o é com qualquer conteúdo crítico, muito antes pelo contrário. Mas o fato é que foram incorporados ao Texto Magno direitos que, embora formalmente etiquetados de fundamentais, não ostentam a clássica caracterização de direitos relativos à indeclinável condição de indivíduo. Além disso, a Constituição de 1988 dotou os direitos e garantias fundamentais de aplicabilidade imediata, como se lê do $\S 1^{\circ}$ do artigo $5^{\circ}$ da Norma Normarum.

\footnotetext{
${ }^{21}$ KELSEN, Hans. A democracia. São Paulo: M. Fontes, 1993. p. 23-107.

22 BINENBOJM, Gustavo. A nova jurisdição constitucional brasileira: legitimidade democrática e instrumentos de realização. Rio de Janeiro: Renovar, 2001. p. 104-105.

${ }^{23}$ Um exemplo recente da preocupação da jurisdição constitucional com o direito das minorias foi o julgamento, pelo Supremo Tribunal Federal, do MS 24.849, Rel Min. Celso de Mello. Na ocasião, a Excelsa Corte reconheceu que o caso tratado no writ atendia aos requisitos do $\S 3^{\circ}$ do art. 58 da $\mathrm{CF}$ e, nessa toada, concluiu pela afronta ao direito público subjetivo às minorias legislativas de ver instaurado o inquérito parlamentar, com apoio no direito de oposição, legítimo consectário do princípio democrático.

${ }^{24}$ Refiro-me, aqui, à acepção mais ampla de direitos fundamentais, segundo a qual tais direitos buscam criar e manter os pressupostos elementares de uma vida na liberdade e na dignidade humana.

PRISMAS: Dir., Pol.Pub. e Mundial., Brasília, v.3, n, 2, p 350-366, jul/dez.2006 
O sempre atualizado magistério de J. J. Gomes Canotilho ${ }^{25}$ indica que os direitos fundamentais possuem uma tríplice função. Podem os direitos fundamentais assumir uma função de defesa ou de liberdade e, nessa condição, instituem um não-fazer estatal, assegurando, ainda, o direito subjetivo de o individuo exigir do Estado uma determinada conduta negativa (são, na verdade, as liberdades públicas clássicas de inspiração eminentemente liberal). Mas os direitos fundamentais podem, ainda, ter uma função de prestação social. Nesse caso, eles asseguram o direito de exigir do Poder Público um fazer estatal, ou seja, garantem o direito de exercer positivamente alguns direitos fundamentais. Por fim, assesta o professor português que os direitos fundamentais ostentam a função de proteção do indivíduo perante terceiros e, nessa perspectiva, impõem o dever de o Estado proteger os titulares dos direitos fundamentais.

Infere-se, portanto, que os direitos fundamentais outorgam direitos subjetivos aos indivíduos. No entanto, eles também podem ser vistos como base do Ordenamento Jurídico de um determinado Estado de Direito Democrático. Assim, se é verdade que os direitos fundamentais asseguram direitos subjetivos aos indivíduos, não é menos correto que tais direitos devem vincular a atividade a ser desempenhada pelo Estado, seja ela legislativa, executiva ou judicante.

Se é assim, a defesa dos direitos fundamentais por um Tribunal Constitucional pode ser realizada de duas formas: a primeira, quando a Corte Constitucional reconhece a inconstitucionalidade de um ato normativo materialmente inconciliável com os direitos fundamentais, e a segunda quando o Tribunal Constitucional, ao julgar uma determinada questão, assegura o pleno gozo de alguns direitos fundamentais assegurados pela ordem constitucional.

Nessa ampla moldura, a conclusão a que podemos chegar é única: a missão do Tribunal Constitucional ultrapassa a mera função de legislador negativo. Em verdade, o sumo papel institucional da Corte Constitucional é o de impor o respeito dos direitos fundamentais às maiorias. E, no desempenho desse mister, convém ainda destacar que a jurisdição constitucional termina por suscitar o debate público em torno dos princípios insertos na Carta Política. Daí a oportuna lição de Erhard Denninger citado por Gilmar Ferreira Mendes ${ }^{26}$

\footnotetext{
${ }^{25}$ CANOTILHO, J. J. Gomes. Direito constitucional e teoria da constituição. 4. ed. Coimbra: Almedina, 2001. p. 401.

${ }^{26}$ MENDES, Gilmar Ferreira. Direitos fundamentais e controle de constitucionalidade. São Paulo: Celso Bastos Editor, 1998. p. 29. 
A forma pela qual a jurisdição constitucional utiliza a competência que lhe foi conferida é essencial para o desenvolvimento da 'Constituição vivida', sobretudo para a efetiva concretização dos direitos da cidadania. A efetividade da proteção dos direitos fundamentais para as minorias socialmente discriminadas e grupos não-privilegiados depende em última instância do Poder Judiciário.

Logo, a jurisdição constitucional não se resume tão-somente ao controle de constitucionalidade dos atos do Poder Público. Em absoluto! O controle de constitucionalidade é apenas um dos aspectos da jurisdição constitucional. Ela deve ser encarada, isto sim, como um instrumento de efetiva proteção (e por que também não dizer concretização?) dos direitos fundamentais. Defender ponto de vista contrário, sem desdouro para ninguém, é reduzir a nobilíssima missão do Tribunal Constitucional, transformando-o em mero legislador negativo.

\section{O Supremo Tribunal Federal e a defesa dos direitos fundamentais}

Como visto no tópico anterior, a tutela dos direitos fundamentais pelo Tribunal Constitucional pode se dar de duas formas: a primeira ocorre quando a Corte exerce o controle de constitucionalidade, e a segunda, quando ela julga uma ação movida ou impetrada por um indivíduo que esteja experimentando algum tipo de restrição no gozo de seus direitos (fundamentais).

Ora bem, de fora parte toda e qualquer discussão acadêmica sobre o definitivo enquadramento do Supremo Tribunal Federal na condição de Corte Constitucional, é evidente que ele desempenha, em algumas situações, competências típicas de um Tribunal Constitucional $^{27}$.

Assim, este trabalho buscou localizar, na riquíssima jurisprudência da Casa Maior da Justiça brasileira, situações em que o pretório Excelso divisou malferimento a algum dos direitos fundamentais consagrados no Texto Maior. E uma dessas situações ocorreu no julgamento Ação Direta de Inconstitucionalidade por Omissão $\mathrm{n}^{\circ} 1.458$, quando a Corte entendeu que fixação do salário-mínimo em valor insuficiente a garantir as necessidades básicas do obreiro e de sua família desrespeita o inciso IV do artigo $7^{\circ}$ da Constituição Federal de 1988. Vejamos o aresto desse julgado na parte que mais diretamente interesse a este estudo:

\footnotetext{
${ }^{27}$ Com relação ao tema, alinho-me ao entendimento de que o Supremo Tribunal Federal não é uma Corte Constitucional, porquanto não detém o monopólio do controle de constitucionalidade e está inserido na estrutura do Poder Judiciário. 
[...] SALÁRIO MÍNIMO - VALOR INSUFICIENTE - SITUAÇÃO DE INCONSTITUCIONALIDADE POR OMISSÃO PARCIAL. - A insuficiência do valor correspondente ao salário mínimo, definido em importância que se revele incapaz de atender as necessidades vitais básicas do trabalhador e dos membros de sua família, configura um claro descumprimento, ainda que parcial, da Constituição da República, pois o legislador, em tal hipótese, longe de atuar como o sujeito concretizante do postulado constitucional que garante à classe trabalhadora um piso geral de remuneração $\left(\mathrm{CF}\right.$, art. $\left.7^{\circ}, \mathrm{IV}\right)$, estará realizando, de modo imperfeito, o programa social assumido pelo Estado na ordem jurídica. [...]

Um outro relevante julgado em tema de direitos fundamentais foi proferido em meados em 2003, no enfrentamento da Questão de Ordem no emblemático HC 82.424 ${ }^{28}$. Nessa ocasião, o Supremo Tribunal ajuizou que a liberdade de expressão, constitucionalmente assegurada, não é absoluta ( $\mathrm{CF}$, inciso IX do art. $5^{\circ}$ ), não podendo, assim, abrigar manifestações de conteúdo imoral que implicam a tipificação do crime de racismo (CF, inciso XLII do artigo $5^{\circ}$ ).

Mais recentemente, ao dar provimento ao Recurso Extraordinário n 436.996 - SP, o Min. Celso de Mello $^{29}$ decidiu:

[...] o Supremo Tribunal Federal, considerada a dimensão política da jurisdição constitucional outorgada a esta Corte, não pode demitir-se do gravíssimo encargo de tornar efetivos os direitos econômicos, sociais e culturais, que se identificam - enquanto direitos de segunda geração (como o direito à educação, p. ex.) - com as liberdades positivas, reais ou concretas.

Nessa mesma linha de pensamento, e também na seara de proteção aos direitos fundamentais, o Min. Carlos Velloso deu provimento ao Recurso Extraordinário n 352-940 SP por entender que ${ }^{30}$ :

[...] o direito à moradia, estabelecido no art. $6^{\circ}$, C.F., é um direito fundamental de $2^{\mathrm{a}}$ geração - direito social — que veio a ser reconhecido pela EC 26, de 2000.

O bem de família - a moradia do homem e sua família — justifica a existência de sua impenhorabilidade: Lei 8.009/90, art. $1^{\circ}$. Essa

\footnotetext{
${ }^{28}$ Disponível em http://www.stf.gov.br/jurisprudencia/nova/pesquisa.asp; acesso em 08-11-2006.

${ }^{29}$ RTJ 164/158-161.

${ }^{30}$ É de se ressaltar, contudo, que, em 08 de fevereiro de 2006, o Supremo Tribunal Federal, em Sessão Plenária, terminou não referendando o ponto de vista manifestado pelo Min. Carlos Velloso no sobredito apelo extremo. Conforme se lê de um trecho do Informativo no 415 do STF: "Continua a ser passível de penhora o bem de família pertencente a fiador em contrato de locação [...] Entendeu-se que a penhora do bem de família do recorrente não viola o disposto no art. $6^{\circ}$ da CF, com a redação dada pela EC 26/2000, mas com ele se coaduna, já que é modalidade de viabilização do direito à moradia — o qual não deve ser traduzido, necessariamente, como o direito à propriedade imobiliária ou o direito de ser proprietário de imóvel — porquanto, atendendo à própria ratio legis da exceção prevista no art. $3^{\circ}$, VII, da Lei 8.009/90, facilita e estimula o acesso à habitação arrendada, constituindo reforço das garantias contratuais dos locadores, e afastando, por conseguinte, a necessidade de garantias mais onerosas, tais como a fiança bancária [...]”. RE 407.688/SP, Rel. Min. Cezar Peluso, DJ, 06/10/2006, p. 33.
}

PRISMAS: Dir., Pol.Pub. e Mundial., Brasília, v.3, n, 2, p 350-366, jul/dez.2006 
impenhorabilidade decorre de constituir a moradia um direito fundamental. $[\ldots]$

Cabe resgatar, por derradeiro, a decisão tomada no RE 472.707, Rel Min. Celso de Mello, caso em que o Supremo Tribunal Federal reconheceu a omissão estatal na prestação do direito fundamental à educação, impondo ao Poder Público o dever de matricular um menor de seis anos de idade em uma das creches mantidas pelo Município.

\section{Conclusão}

Pelo exposto, pode-se concluir que a idéia de regularidade constitucional outra coisa não significa senão um exame de compatibilidade dos atos do Poder Público com a Constituição. Sabido que nela -- Constituição - repousam tanto as normas que regulam o procedimento da legislação (inclusive no tocante à distribuição de competência entre os órgãos e autoridades estatais partícipes do processo legiferante) quanto às normas que veiculam os direitos fundamentais do indivíduo. Logo, um eventual deslize do Poder Público na elaboração de um determinado ato pode inquiná-lo de duas maneiras: formalmente, caso não sejam observadas as normas constitucionais atinentes ao processo legislativo e, ainda, materialmente, caso o conteúdo do ato estatal contrarie algum direito fundamental encartado na Constituição.

Se é assim, vale dizer, já que o ato do Poder Público pode mesmo contrariar a vontade constitucional, é preciso criar alguns instrumentos para garantir a supremacia da Constituição. E o fato é que, de todas os mecanismos já idealizados, o que mais atende à finalidade pretendida é a anulação do ato inconstitucional por um órgão especialmente incumbido nessa tarefa: o Tribunal Constitucional.

Sucede que a jurisdição constitucional não se resume, apenas, ao controle de constitucionalidade. A ela incumbe uma tarefa que transcende o simples papel de legislador negativo, que é a de impor a observância dos direitos fundamentais. Nesse diapasão, impõe-se reconhecer a vital importância da jurisdição constitucional para garantir a efetividade dos direitos fundamentais, bem como manter e aperfeiçoar o regime democrático. Assim, além de cumprir a tarefa de aferir a regularidade dos atos normativos com a Lei Maior, a jurisdição constitucional deve assegurar o pleno gozo dos direitos fundamentais, naquela tríplice feição ensinada por J. J. Gomes Canotilho: função de defesa ou de liberdade, função de prestação social e função de proteção do indivíduo perante terceiros. 
De outra banda, também é papel da jurisdição constitucional impedir a sujeição das minorias aos caprichos e arbitrariedades perpetrados pela maioria. E, desse modo, a minoria também tem a possibilidade de influenciar, de colaborar, enfim, de participar ativamente da formação da vontade geral.

Artigo recebido em agosto de 2006

Aceito em setembro de 2006

\section{Referências}

BARBOSA, Ruy. A Constituição e os atos inconstitucionais do Congresso e do Executivo. 2. ed. Rio de Janeiro: Atlântica, 1893.

BARBOSA, Ruy. Comentários à Constituição Federal Brasileira. São Paulo: Saraiva, 1932-1934.

BINENBOJM, Gustavo. A nova jurisdição constitucional brasileira: legitimidade democrática e instrumentos de realização. Rio de Janeiro: Renovar, 2001.

BONAVIDES, Paulo. Jurisdição constitucional e legitimidade: algumas observações sobre o Brasil. Anuário Iberoamericano de Justiça Constitucional, São Paulo, v. 7, 2003, p. 77 78.

CANOTILHO, J. J. Gomes. Direito constitucional e teoria da constituição. 4. ed. Coimbra: Almedina, 2001.

CRUZ, Álvaro Ricardo de Souza. Jurisdição constitucional democrática. Belo Horizonte: Editora Del Rey, 2004.

FERREIRA, Pinto. O Judiciário e a Constituição. São Paulo: Saraiva, 1994.

FERREIRA FILHO, Manoel Gonçalves Direitos humanos fundamentais. $6^{\text {a }}$ ed., São Paulo: Saraiva, 2004.

KELSEN, Hans. A democracia. São Paulo: M. Fontes, 1993.

KELSEN, Hans. A jurisdição constitucional. São Paulo: M. Fontes, 2003.

KIMMINICH, Otto. A jurisdição constitucional e o princípio da decisão de poderes. Revista de Informação Legislativa, Brasília, v 27, nº 105, p. 283-302, jan/mar 1990.

MENDES, Gilmar Ferreira. Direitos fundamentais e controle de constitucionalidade. São Paulo: Celso Bastos Editor, 1998. 
MONTESQUIEU. O espírito das leis. Brasília: Editora UnB, 1995.

ROCHA, Carmem Lúcia Antunes. Constituição e constitucionalidade. Belo Horizonte: Lê, 1991.

ROYO, Javier Perez. Tribunal constitucional y division de poderes. Madrid: Tecnos, 1988.

SILVA, José Afonso da. Da jurisdição constitucional no Brasil e na América Latina. Revista da Procuradoria Geral do Estado de São Paulo, São Paulo, no 13/15, p. 111, dez/1978dez/1979. 


\section{Resumo}

O objeto deste artigo é estudar o papel da jurisdição constitucional enquanto mecanismo de defesa dos direitos fundamentais. Para tanto, examinaremos, num primeiro momento, a idéia de regularidade das normas jurídicas. Em seguida, faremos algumas reflexões acerca das garantias de constitucionalidade dos atos do Poder Público e examinaremos o papel da jurisdição constitucional como instrumento de defesa dos direitos fundamentais, analisando alguns julgados do Supremo Tribunal Federal.

Palavras-chave: Jurisdição e constitucional e direitos fundamentais

\section{Abstract}

The objective of this article is studying the rule of constitucional jurisdiction as fundamental rights mechanism of defense. Firstly, we will examine the idea of juridical compatibility. After that, we will make some reflections concerning the constitutionality guarantees of constitutionality of the acts of the State and, finally, we will examine the rule of the constitutional jurisdiction as defense instrument of the basic rights, analyzing some Supreme Federal Court judgement precedents.

Key words: jurisdiction and constitucional and fundamental rights 